\title{
LITERACY DEVELOPMENT DENGAN METODE FONIK BAGI ANAK USIA DINI
}

\author{
Oleh \\ Putu Santi Oktarina \\ Institut Hindu Dharma Negeri Denpasar \\ Email: putusantioktarina@gmail.com
}

\begin{abstract}
This article discusses the content and instructional plans of phonetic methods as well as word recognition to be used by early childhood for reading. The information provided is about the content of effective word recognition instructions. Guidelines are included based on this information as well as on some other aspects of reading instruction, they are, the development of spoken language, awareness of writing in print, reading aloud, and independent reading) which are important for any accessible and effective class program. This guide will assist educators in choosing programs that allow all children to be successful in learning to read. There are many objectives of teaching reading, including, of course, that children will read with confidence, that they will understand what they read, and that they will find a source of knowledge and pleasure from reading. To achieve this goal with all children, an effective classroom program of early reading instruction should be provided to children with various experiences related to a number of important aspects of reading.
\end{abstract}

\section{Keywords: Literacy Development, Phonic Method, Early Childhood}

\begin{abstract}
Abstrak
Artikel ini membahas konten dan rencana instruksional dari metode fonik serta pengenalan kata untuk digunakan oleh anak-anak usia dini dalam membaca. Informasi yang diberikan adalah tentang isi instruksi pengenalan kata yang efektif. Pedoman disertakan berdasarkan informasi ini serta pada beberapa aspek lain dari instruksi membaca, yaitu, pengembangan bahasa lisan, kesadaran mengenai tulisan dalam bentuk cetak, membaca dengan keras, serta membaca lebih luas secara independen) yang penting bagi setiap program kelas yang dapat diakses dan efektif. Panduan ini akan membantu pendidik dalam memilih program yang memungkinkan semua anak menjadi sukses dalam belajar membaca. Terdapat banyak tujuan dari pengajaran membaca, tentu saja termasuk bahwa anak-anak akan membaca dengan percaya diri, bahwa mereka akan memahami apa yang mereka baca, dan bahwa mereka akan menemukan sumber pengetahuan dan kesenangan dari kegiatan membaca. Untuk mencapai tujuan ini dengan semua anak, program kelas yang efektif dari instruksi membaca awal harus diberikan kepada anak-anak dengan berbagai pengalaman yang berhubungan dengan sejumlah aspek penting dari membaca.
\end{abstract}

\section{Kata Kunci: Literacy Development, Metode Fonik, Anak Usia Dini}

\section{PENDAHULUAN}

Banyak sekolah di luar negeri telah mengembangkan program-program fonik dan instruksi pengenalan kata. Beberapa instruksi pengenalan kata-kata dan fonik terintegrasi dalam programmembaca yang besar dan yang lainnya dalam programprogram tambahan yang difokuskan 
secara sempit untuk membahas satu aspek dari instruksi. Banyak guru mengajarkan fonik dan pengenalan kata dengan menggunakan program membaca yang diterbitkan secara komersial, biasanya program pengajaran yang mencakup materi tingkat kelas untuk mengajar membaca dengan panduan guru dan bahan bacaan siswa serta bahan tambahan yang mendukung komponen utama. Program-program ini sering mengandung aktivitas-aktivitas fonik dan pengenalan kata yang tertanam dalam urutan instruksi yang mencakup pembacaan bersama dari literatur anak-anak, pembacaan terpandu dalam cerita-cerita yang dapat diprediksi, dan kegiatan menulis. Program membaca ini sangat penting karena biasanya diadopsi oleh sekolah unggulan dan menjadi landasan instruksi bagi sebagian besar ruang kelas. Ulasan terbaru dari program komersial utama (Smith et al., Dalam pers; Stein, Johnson, \& Gutlohn, 1998) telah mengungkapkan bahwa instruksi pengenalan kata dan instruksi dalam keterampilan berbahasa lisan yang berhubungan dengan pengenalan kata tidak cukup terwakili. Stein dkk. menemukan bahwa beberapa program termasuk pendekatan fonik yang eksplisit, dan pilihan bacaan siswa sering tidak sesuai dengan kata-kata yang dipelajari anak-anak selama pengajaran pengenalan kata yang membuat sebagian besar pilihan tidak dapat diakses oleh pembaca.

Selain program ini, para guru sering melengkapi instruksi reguler mereka dengan program-program fonik yang diterbitkan. Program-program ini biasanya digunakan dengan siswa yang diidentifikasi memiliki ketidakmampuan membaca. Banyak orang tua mencari program semacam itu untuk digunakan di rumah jika mereka khawatir anakanak mereka mengalami kesulitan untuk belajar membaca di sekolah. Ada ratusan program tambahan, dan programprogram baru muncul secara teratur. Program-program ini memiliki banyak bentuk. Banyak muncul dalam bentuk cetak tradisional yang menampilkan permainan papan dan kartu, kartu flash, daftar kata, buku cerita, dan buku kerja. Beberapa menggabungkan bahan instruksional tradisional dengan audiotape, permainan elektronik, kaset video, dan komputer. Program lain pada dasarnya menyediakan semua instruksi yang dapat diakses melalui komputer. Meskipun hubungan antara fonik yang sistematis dan instruksi pengenalan kata terhadap prestasi membaca adalah topik yang banyak diperdebatkan, setiap diskusi yang tercerahkan oleh para pendukung instruksi tersebut menekankan bahwa itu harus menjadi bagian dari program instruksi total (Snow, Bums, \& Griffin, 1998). Tujuan utama dari instruksi tersebut adalah untuk membantu anakanak mengetahui sistem abjad Bahasa Inggris tertulis dan menjadi nyaman dengan sistem itu ketika mereka menjadi pembaca (Lyon, 1998).

Tujuan dari phonics bukan bahwa anak-anak dapat menyatakan "aturan" yang mengatur hubungan huruf dan bunyi. Sebaliknya, tujuannya adalah untuk mendapatkan prinsip abjad, prinsip bahwa ada hubungan sistematis antara huruf dan bunyi. Fonik haruslah 
dipahami sebagai teknik untuk membuat anak-anak memulai dengan cepat dalam memetakan hubungan antara huruf dan bunyi. Oleh karena itu, instruksi fonik harus bertujuan untuk hanya mengajarkan hubungan antara huruf dan bunyi yang paling penting dan teratur, karena ini adalah jenis instruksi yang akan paling langsung meletakkan prinsip abjad. Begitu hubungan dasar telah diajarkan, cara terbaik untuk membuat anak-anak menyempurnakan dan memperluas pengetahuan mereka tentang korespondensi huruf dan bunyi adalah melalui kesempatan membaca secara berulang. (hlm. 38). Fonik kemudian dapar dimaknai sebagai sistem instruksi yang digunakan untuk mengajarkan anakanak hubungan antara huruf dan bunyi (Snow et al., 1998).

Bagian penting dari membantu anak-anak membaca dan mencari tahu sistem yang mendasari kata tercetak adalah membimbing mereka untuk memahami prinsip abjad (Adams, 1990; Ehri \& McCormick, 1998; Liberman, Shankweiler, \& Liberman, 199 1). Ini berarti, untuk memahami bahwa dalam bahasa Inggris tertulis, kata-kata terdiri dari pola huruf yang mewakili bunyi kata-kata bahasa Inggris yang diucapkan. Beberapa anak tampaknya memahami prinsip abjad dengan mudah, dengan sedikit atau tanpa instruksi. Namun, sebagian besar anak-anak, dan anakanak dengan ketidakmampuan belajar (LD) khususnya, mendapat manfaat dari pengajaran terorganisasi yang berpusat pada bunyi, huruf, dan hubungan antara bunyi dan huruf (Perfetti \& Zhang,
1995). Mereka juga mendapat manfaat dari instruksi pengenalan kata yang menawarkan praktek dengan keluarga kata yang memiliki pola huruf yang mirip. Selain itu, anak-anak tentunya mendapat manfaat dari peluang untuk menerapkan apa yang mereka pelajari untuk membaca sebuah teks. Teks-teks seperti itu mengandung proporsi kata-kata yang tinggi yang mencerminkan huruf, suara, dan pola ejaan yang dipelajari oleh anakanak.

\section{PEMBAHASAN}

\subsection{Pengenalan Literasi pada Anak Usia Dini}

Literasi yang dalam bahasa Inggrisnya Literacy berasal dari bahasa Latin littera (huruf) yang pengertiannya melibatkan penguasaan sistem-sistem tulisan dan konvensi-konvensi yang menyertainya. Kendatipun demikian, literasi utamanya berhubungan dengan bahasa dan bagaimana bahasa itu digunakan. Lebih lanjut Literasi merupakan kemampuan yang terkait dengan kemampuan membaca, menulis, menyimak dan berbicara. Sependapat yang disampaikan oleh Laurie \& Whitehead (2004) mengemukakan bahwa literasi anak merupakan kemampuan yang berkaitan dengan, membaca, menulis, menyimak dan berbica. Secara sederhana, literasi berarti kemampuan membaca dan menulis, atau melek aksara (Resmini, 2010). Dalam konteks sekarang, literasi memiliki arti yang sangat luas. Literasi dapat berarti melek teknologi, politik, berpikiran kritis, dan peka terhadap lingkungan sekitar. 
Widayati (2011) mendefinisikan literasi kontemporer sebagai kemampuan seseorang dalam menggunakan informasi tertulis atau cetak untuk mengembangkan pengetahuan, sehingga mendatangkan manfaat bagi masyarakat. Lebih jauh, seorang baru dapat dikatakan literat jika ia sudah dapat memahami sesuatu karena membaca dan melakukan sesuatu berdasarkan pemahaman bacaannya.

Menurut hemat Justice dan Kaderavek (2002) mengatakan bahwa periode literasi anak mulai dari lahir sampai dengan usia enam tahun. Pada periode tersebut anak-anak memperoleh pengetahuan tentang membaca dan menulis tidak melalui pengajaran, tetapi melalui perilaku yang sederhana dengan mengamati dan berpartisipasi pada aktivitas yang berkaitan dengan literasi. Pengajaran formal tidak selalu diperlukan untuk mengembangkan literasi emergen. Dengan mengamati orang yang melakukan aktivitas literasi dan berpartisipasi dengan aktivitas tersebut maka anak akan memperoleh kemampuan yang merupakan prasyarat penting untuk mengembangkan membaca konvensional.

Berkenaan dengan ini Kern (2000) mendefinisikan istilah literasi secara komprehensif sebagai berikut:

Literacy is the use of
socially-, and historically-,
and culturally-situated
practices of creating and
interpreting meaning through
texts. It entails at least
a tacit awareness of the
relationships between textual
conventions and their context

Literacy is the use of socially-, and historically-, and culturally-situated practices of creating and interpreting meaning through texts. It entails at least a tacit awareness of the conventions and their context of use and, ideally, the ability to reflect critically on those relationships. Because it is purpose-sensitive, literacy is dynamic - not static - and variable across and within discourse communities and cultures. It draws on a wide range of cognitive abilities, on knowledge of written and spoken language, on knowledge of genres, and on cultural knowledge.

MenurutNutbrown \& Claugh(2015) mengemukakan bahwa pengenalan literasi bagi anak anak mulai dikembangakan terlebih di Inggris sejak tahun 1980-an karena para guru dan peneliti melihat jika pentingnya mengenalkan atau membelajarkan literasi membaca dan menulis bagi anak usia dini. Senada yang disampaikan oleh Chomsky (Subyantoro, 2012) pemerolehan literasi anak pada dasarnya ia akan menginternalisasikan sistem kaidah yang berhubungan dengan bunyi dan makna secara khusus dan anak memperoleh kemampuan lietrasi dengan cara yang sangat menakjubkan. Lebih lanjut Montessori dan Maturationis (Moriison, 2013) mengemukakan bahwa, penguasaan bahasa adalah pembawaan lahir pada semua anak tanpa memandang budaya dan agamnya. Artinya bahwa sejak lahir sampai dengan usia 6 tahun anak usia dini sudah mempunyai kemampuan dalam literasi, meskipun tidak belajar secara khusus tetapi anak belajar bahasa memlalui interaksi dengan lingkungan dimana anak tinggal. 
Anak memiliki Pengalaman literasi sebelum mereka pergi ke sekolah dan apa yang mereka ketahui tentang keaksaraan sangat penting bagi perkembangan mereka. Anak belajar aksaraan pertama kali didapat dari rumah mereka masingmasing melalui interaksi dengan orang tua dan dengan cara yang menyenangkan tanpa adanya intimidasi (Makin L, \& Whitehead M, 2004). Gambaran lingkungan keluarga dan lingkungan sekolah yang kondusif menstimulasi kemampuan literasi anak mengenai kemampuan mambaca dan menulis Nutbrown \& Claugh (2015). Kemampuan literasi awal anak adalah suatu proses kemampuan yang dimulai pada saat lahir dan terus berkembangn selama masa hidup. Anak-anak mempelajari literasi dengan cara yang sangat menakjubkan. Menurut Montessori (Morrison, 2013) mengemukakan bahwa, penguasaan bahasa adalah pembawaan lahir pada semua anak tanpa memandang budaya dan agamnya.

Dari uraian dan pendapat para ahli di atas dapat dikatakan bahwa literasi anak usia dini adalah kemampuan yang dimiliki oleh anak terkait dengan kemampuan membaca dan menulis. Pengenalan literasi anak usia dini adalah suatu proses aktivitas yang memperkenalkan kemampuan membaca, menulis pada anak usia dini; tanpa adanya unsur intimidasi bagi anak untuk mengetahui secara sempurna seperti orang dewasa tetapi membelajarkan lietrasi tersebut sesuai dengan usia atau fase-fase perkembangannya. Pengenalan literasi awal pada anak usia dini dilakukan dengan cara yang menyenangkan sehingga anak tidak merasa jenuh, untuk membelajarkan sesuatu hal yang bermakna bagi eksistensinya.

\subsection{Prinsip Pembelajaran Literasi Pada Anak Usia Dini}

Menurut Kern(2000) Terdapat tujuh prinsip pendidikan literasi diantarannya yaitu: Pertama; Literasi melibatkan interpretasi; Penulis/pembicara dan pembaca/pendengar berpartisipasi dalam tindak interpretasi, yakni: penulis/ pembicara menginterpretasikan dunia (peristiwa, pengalaman, gagasan, perasaan, dan lain-lain), dan pembaca/ pendengar kemudian mengiterpretasikan interpretasi penulis/pembicara dalam bentuk konsepsinya sendiri tentang dunia. Kedua; Literasi melibatkan kolaborasi; Terdapat kerjasama antara dua pihak yakni penulis/pembicara dan pembaca/pendengar. Kerjasama yang dimaksud itu dalam upaya mencapai suatu pemahaman bersama. Penulis/pembicara memutuskan apa yang harus ditulis/ dikatakan atau yang tidak perlu ditulis/ dikatakan berdasarkan pemahaman mereka terhadap pembaca/pendengarnya. Sementara pembaca/pendengar mencurahkan motivasi, pengetahuan, dan pengalaman mereka agar dapat membuat teks penulis bermakna.

Ketiga; Literasi melibatkan konvensi; Orang-orang membaca dan menulis atau menyimak dan berbicara itu ditentukan oleh konvensi/ kesepakatan kultural (tidak universal) yang berkembang melalui penggunaan dan dimodifikasi untuk tujuan-tujuan 
individual. Konvensi disini mencakup aturan-aturan bahasa baik lisan maupun tertulis.

Keempat; Literasi melibatkan pengetahuan kultural; Membaca dan menulis atau menyimak dan berbicara berfungsi dalam sistem- sistem sikap, keyakinan, kebiasaan, cita-cita, dan nilai tertentu. Sehingga orang- orang yang berada di luar suatu sistem budaya itu rentan/beresiko salah/keliru dipahami oleh orang-orang yang berada dalam sistem budaya tersebut.

Kelima; Literasi melibatkan pemecahan masalah; Karena kata-kata selalu melekat pada konteks linguistik dan situasi yang melingkupinya, maka tindak menyimak, berbicara, membaca, dan menulis itu melibatkan upaya membayangkan hubungan-hubungan di antara kata-kata, frase- frase, kalimatkalimat, unit-unit makna, teks-teks, dan dunia-dunia. Upaya membayangkan, memikirkan, mempertimbangkan ini merupakan suatu bentuk pemecahan masalah.

Keenam; Literasi melibatkan refleksi dan refleksi diri; Pembaca/ pendengar dan penulis/pembicara memikirkan bahasa dan hubunganhubungannya dengan dunia dan diri mereka sendiri. Setelah mereka berada dalam situasi komunikasi mereka memikirkan apa yang telah mereka katakan, bagaimana mengatakannya, dan mengapa mengatakan hal tersebut.

Ketujuh; Literasi melibatkan penggunaan bahasa; Literasi tidaklah sebatas pada sistem-sistem bahasa (lisan/tertulis) melaikan mensyaratkan pengetahuan tentang bagaimana bahasa itu digunakan baik dalam konteks lisan maupun tertulis untuk menciptakan sebuah wacana/diskursus.

\subsection{Stimulasi Perkembangan Literasi (Membaca \& Menulis) Anak Usia Dini}

Tidak bisa dipungkiri saat ini banyak ahli PAUD yang memandang pentingnya pengenalan literasi (membaca dan menulis) pada anak usia dini. Menurut Suyadi (2010) mengemukakan bahwa kemampuan litreasi dapat diperkenalkan atau diajarkan kepada anak usia dini sejak anak berada dalam kandungan. Berikut adalah uraian stimulasi perkembangan lietrasi pada anak usia dini untuk mengembangkan kemampuan literasi sebagi berikut:

Bayi (Infants); sejak dalam kandungan idealnya anak mampu distimulasi atau diperkenanlkan berbagai aktivitas yang mendorong anak untuk mengembangkan kemampuan literasi. Kegiatan membaca dan menulis pada anak usia dini merupakan bukan kegiatan yang dalam artian orang dewasa. Pembelajaran literai pada anak usia bayi McGee dan Purcell-Gates (Abidin, 2015) menyebutkan bahwa perkembangan literasi berisi dua periode waktu, secara rinci dimulai dari lahir sampai usia lima tahun dan dari usia lima tahun sampai dengan menjadi pembaca yang mandiri (konvensional).

Pengenalan literasi bisa dilakukan pada saat ia berbaring, tengkurang atau duduk. Bahkan di atas tempat tidur anak di taruhkan buku-buku berwarna (full 
colour) atau orang tua membacakan ia cerita. Karena pada dasarnya menurut. Perlu diketahui bahwa pengenalan literasi pada bayi kita hanya sebatas memperkenalkan saja bukan memaksa anak untuk menghafal.

Toddlers (2-3 tahun); Pada dasarnya Toldders sangat gemar akrab dengan buku. Jika stimulasi di atas berhasil anak-anak akan mempunyai kecenderungan untuk menyukai buku. Beberapa penelitian menunjukan bahwa anak yang sejak dini akrab dengan dunia buku kelak dimasa dewasa ia kan mempunyai minat baca yang tinggi Suyadi (2010). Umumnya pada masa ini anak-anak mulai membaca, gemar memberikan nama pada objekobjek yang ada dalam buku tersebut.

Seiring berjalannya waktu dan bertambahnya kosa kata atau tanda yang dikenali, mulailah memperkenalkan anak untuk membaca tetapi bukan untuk menghafal. Awal mula kita sendiri yang membacanya dengan suara nyaring terhadap isi buku tersebut. suara nyaring dan intonasi yang tepat merupakan langkah yang paling strategis menstimulai pendengraan anak.

Anak usia 3- 6 tahun; Pada taha ini menurut Suyadi (2010) kesenangan anak terhadap buku cerita mulai meningkat tajam. Walaupun demikian pada tahap ini anak masih menyukai buku-buku cerita yang masih banyak ilustrasi gambargambar, dan warnah-warna cerah. Karena pada hakikatnya menurut Kaderavek (2002) mengatakan bahwa periode literasi anak mulai dari lahir sampai dengan usia enam tahun. Dengan demikian pemberian literasi yang paling bagik bagi anak pada tahap ini adalah membacakan cerita, kisah membacakan dongeng. Cara lain adalah meminta anak menceriatakan ulang dinging atau cerita tersebut walaupun tidak selengkap cerita aslihnya. Selain membacakan dongeng langkah selanjutny membelajarkan literasi adalah dengan menyusun kata-kata bersajak.

\subsection{Unsur-Unsur Fonik dan Instruksi Pengenalan Kata}

Untuk membantu anak memetakan hubungan antara huruf dan bunyi, fonik yang efektif dan instruksi strategi pengenalan, guru harus memberi siswa kesempatan untuk menjadi nyaman dengan sejumlah aspek membaca, termasuk pengetahuan alfabetik, kesadaran fonemik, hubungan simbol suara, identifikasi kata strategi, koneksi ejaan dan penulisan, latihan membaca terkait, dan kelancaran membaca.

\subsubsection{Pengetahuan Alfabet}

Anak-anak harus menjadi pengguna ahli dari huruf yang akan mereka lihat dan gunakan untuk menulis kata-kata dan pesan mereka sendiri (Lyon, 1998). Pengetahuan anak-anak tentang huruf adalah prediktor kuat dari kesuksesan mereka dalam belajar membaca (Adams, 1990). Artinya, anak yang pada usia dini mampu dengan cepat dan akurat mengidentifikasi, mengatakan, dan menulis huruf-huruf alfabet memiliki keuntungan dalam belajar membaca. Anak-anak yang pengetahuannya tentang surat tidak berkembang dengan baik ketika mereka mulai sekolah membutuhkan banyak praktik yang terorganisir dengan 
bijaksana yang akan membantu mereka belajar bagaimana mengidentifikasi, menyebutkan nama, dan menulis huruf.

\subsubsection{Panduan Instruksi Pengetahuan mengenai Abjad}

Program membaca awal harus mencakup unsur-unsur berikut:

1. Berbagai aktivitas pengetahuan alfabet di mana anak-anak belajar untuk mengidentifikasi dan memberi nama huruf besar dan huruf kecil.

2. Game, lagu, dan aktivitas lain yang membantu anak-anak belajar menyebutkan huruf dengan cepat.

3. Kegiatan menulis yang mendorong anak-anak untuk berlatih menulis huruf yang mereka pelajari.

4. Urutan pengantar huruf yang masuk akal yang dapat disesuaikan dengan kebutuhan anak-anak.

\subsubsection{Kesadaran fonemik}

Kemampuan anak-anak untuk berpikir tentang kata-kata individu sebagai urutan bunyi penting untuk pemahaman mereka tentang prinsip abjad (Liberman \& Shankweiler, 1985; Snow et al., 1998). Terhadap pemahaman itu, anak-anak belajar mengidentifikasi kata-kata syair dan menciptakan rima mereka sendiri. Mereka juga belajar bahwa kalimat terdiri dari kata-kata yang terpisah, katakata terdiri dari suku kata, dan kata-kata terdiri dari suara yang dapat dipisahkan satu sama lain dan dimanipulasi dengan cara lain. Akhirnya, mereka belajar bahwa bunyi yang terpisah (atau tersegmentasi) dari kata-kata dapat disatukan kembali untuk membentuk kata-kata.
Beberapa anak memiliki banyak kesulitan belajar untuk memisahkan, atau menyegmentasikan, bunyi-bunyi dalam kata-kata yang diucapkan, dan untuk kemudian menyusun kembali bunyibunyi (yaitu, untuk memadukan suarasuara tersegmentasi kembali bersamasama untuk membuat sebuah kata; O'Connor, Notari-Syverson, \& Vadasy, 1998). Namun, aspek kesadaran fonemik inilah yang memungkinkan anak-anak untuk menerapkan pengetahuan mereka tentang hubungan surat suara dengan suara yang keluar dari kata-kata tercetak (Smith, Simmons, \& Karneenui, 1998).

Penting untuk membuat beberapa perbedaan yang jelas: Fonem adalah bunyi individual yang terpisah dalam kata-kata. Itu adalah unit suara terkecil. Onset adalah fonem tunggal awal atau klaster konsonan awal dalam satu kata dan rime adalah himpunan fonem yang tersisa dalam satu kata. Rimes lebih besar dari fonem, tetapi lebih kecil dari suku kata. Sebagian besar urutan instruksi kesadaran fonemik dimulai dengan kata-kata syair dan kemudian bergerak untuk membantu anak-anak belajar bagaimana membagi (atau membagi) kalimat menjadi katakata, kata-kata menjadi suku kata, kata menjadi onset dan rime, dan akhirnya, kata-kata satu suku kata menjadi fonem.

Tidak semua program menyertakan konten yang sama. Sebagai contoh, beberapa program memperkenalkan onset dan rimes sebelum mengharuskan siswa untuk mengidentifikasi dan memanipulasi setiap suara yang dipisahkan dari satu kata kata. Beberapa program tidak termasuk aktivitas onset 
dan rime. Dalam banyak program, segmentasi diperkenalkan dengan meminta anak-anak mengidentifikasi dan menyegmentasikan bunyi awal dari satu kata suku kata. Setelah berlatih dengan bunyi awal, anak-anak kemudian belajar mengidentifikasi dan menyegmentasikan bunyi akhir, dan akhirnya bekerja dengan suara medial. Masih ada program lain yang membuat anak-anak belajar untuk menyegmentasikan dan kemudian memadukan masing-masing suara dari kata-kata satu suku kata yang diucapkan.

Aktivitas kewaspadaan fonemik biasanya melibatkan tugas lisan tanpa adanya cetakan. Namun, dalam beberapa program, instruksi mengarahkan anakanak untuk menggunakan pendengaran (bertepuk tangan) dan isyarat visual (kotak Elkonin, blok) untuk membantu mereka memahami bahwa bunyi dalam kata-kata dapat menjadi entitas yang terpisah. Pada tingkat yang lebih maju dari instruksi (segmentasi dan pencampuran), hubungan bunyi ke huruf yang ditulis sering menjadi bagian dari urutan instruksional, sehingga anak-anak mendengar dan melihat hubungan antara bunyi dan huruf.

\subsubsection{Panduan untuk Instruksi Kesadaran Fonemik}

Program membaca awal harus mencakup unsur-unsur berikut:

Aktivitas yang mengikuti urutan instruksi yang berkembang dari tugas yang lebih mudah ke tugas yang lebih sulit dan dari yang lebih besar ke unit yang lebih kecil, misalnya:
Kata kata berirama.

Membagi kalimat menjadi kata-kata.

Membagi kata menjadi suku kata.

Segmentasi dan pencampuran onset dan rimes.

Mengidentifikasi bunyi awal, tengah, dan akhir dalam kata-kata yang diucapkan.

Segmentasi dan perpaduan suara individu (fonem) dalam kata-kata yang diucapkan.

Auditori (misalnya, tepuk tangan), visual (misalnya, ubin, keping), atau kedua isyarat untuk membantu anak-anak mengidentifikasi bunyi terpisah dalam kata-kata.

Kegiatan untuk mengajarkan hubungan huruf dengan suara dalam tugas yang lebih maju (segmentasi dan blending phonemes).

\subsubsection{Strategi Pengenalan Kata}

Strategi pengenalan kata yang efektif memungkinkan anak-anak untuk secara cepat dan otomatis menerjemahkan huruf-huruf atau pola-pola ejaan katakata tertulis ke dalam bunyi-bunyi ujaran sehingga mereka dapat mengidentifikasi kata-kata dan memperoleh akses cepat ke maknanya (Vandervelden \& Siegel, 1997). Anak-anak harus belajar untuk mengidentifikasi kata-kata dengan cepat dan mudah sehingga mereka dapat fokus pada makna dari apa yang mereka baca (Stanovich, 1997). Ketika anak-anak belajar membaca lebih banyak cerita yang lebih kompleks, strategi identifikasi kata yang efektif akan memungkinkan mereka untuk mengetahui pelafalan kata-kata yang belum pernah mereka baca sebelumnya. Pengetahuan semantik 
dan sintaksis siswa, pada gilirannya, dapat membantu untuk mengkonfirmasi keakuratan usaha mereka dalam identifikasi kata.

Penting bahwa anak-anak belajar menggunakan pengetahuan bunyi dan ejaan mereka sebagai strategi utama untuk pengenalan kata (Bay Area Reading Task Force, 1997; Beck, 1998). Anakanak juga harus memiliki kesempatan untuk bekerja dengan unit yang lebih besar (mis., Keluarga kata, pola ejaan, dan onset dan rimes). Strategi identifikasi kata yang lebih canggih berfokus pada analisis struktural - identifikasi kata-kata dasar, awalan, dan akhiran - dan tentang cara membaca kata-kata yang bertingkat banyak. Anak-anak perlu mengenali beberapa kata umum sebelum mereka memiliki pengetahuan huruf suara untuk membunyikannya ( misal, ini, ini). Selain itu, beberapa kata "tidak beraturan", yang berarti mereka sulit dibaca menggunakan strategi yang terdengar. Program harus memperkenalkan beberapa kata penglihatan yang tidak beraturan dan lainnya dalam urutan yang masuk akal. Kata-kata ini harus terus menerus ditinjau dalam pelajaran dan dalam materi tertulis yang dibaca anak-anak. Menyajikan beberapa kata sebagai kata-kata penglihatan seharusnya tidak membayangi pentingnya mengajar anak-anak untuk belajar bagaimana menggunakan strategi identifikasi kata untuk mencari tahu kata-kata.

\subsubsection{Ejaan dan Tulisan}

Anak-anak ketidakmampuan membaca harus memiliki kesempatan untuk menulis dan menghubungkan tulisan mereka dengan ejaan dan membaca. Awalnya, perkiraan fonetik anak-anak kata-kata atau ejaan yang diciptakan harus didorong untuk merangsang penulisan (Ehri, 1998; Snow et al., 1998). Ketika anak-anak belajar membaca dan menulis kata-kata, mereka menjadi sadar bagaimana katakata ini dieja. Meningkatkan kesadaran anak-anak akan pola ejaan mempercepat kemajuan mereka dalam membaca dan menulis. Di kelas pertama, instruksi ejaan dapat dikoordinasikan dengan program instruksi membaca. Seiring kemajuan anak-anak, pelajaran sistematis dalam pengejaan sangatlah penting.

\subsubsection{Bahasa Lisan dan Peluang Mendengarkan}

Landasan yang lemah dalam bahasa lisan dapat menghambat kemajuan anak dalam membaca (Snow et al., 1998). Untuk memahami bahasa tertulis, anak-anak harus memiliki beberapa keakraban dengan kosakata dan struktur kalimat yang mereka temui dalam cerita dan teks sekolah mereka. Pengalaman bahasa lisan konstruktif di ruang kelas adalah penting untuk semua anak, tetapi khususnya bagi anak-anak dengan ketidakmampuan membaca dan bagi mereka yang memiliki lebih sedikit kesempatan untuk mengembangkan jenis bahasa yang diperlukan untuk membaca. Untuk alasan-alasan ini, instruksi TK perlu memanfaatkan setiap kesempatan untuk melibatkan anak-anak dalam diskusi, penjelasan, dan demonstrasi yang penuh pemikiran. Mendengarkan 
adalah aspek lain dari perkembangan bahasa lisan. Anak-anak perlu mendengarkan dengan saksama untuk mengikuti petunjuk. Mendengarkan pemahaman adalah kontributor penting untuk pemahaman bacaan (Menyuk, 1988). Akibatnya, instruksi TK harus memberikan kesempatan bagi anak-anak untuk mendengarkan serta berbicara. Peluang-peluang ini dapat datang dalam memberi dan mengikuti petunjuk, diskusi kelas, pembacaan buku cerita, dan permainan. Pemahaman anak-anak terhadap bahasa tertulis sangat tergantung pada penggunaan dan pemahaman mereka yang efektif terhadap bahasa lisan (Snow et al., 1998). Pengalaman bahasa merupakan komponen sentral dari instruksi membaca yang baik. Anak-anak belajar banyak tentang dunia, tentang diri mereka sendiri, dan tentang satu sama lain dari bahasa lisan.

\subsubsection{Hubungan Huruf dan Bunyi}

Perkembanganmembaca awal anakanak tergantung pada perolehan hubungan huruf dan bunyi yang mendasari bahasa Inggris tertulis. Banyak anak dengan ketidakmampuan membaca mendapat manfaat dari pengajaran yang eksplisit dan sistematis dari hubungan huruf dan bunyi ini; ini biasanya digambarkan dengan label fonik. Anak-anak dengan ketidakmampuan membaca mendapat manfaat dari serangkaian instruksi fonik yang memungkinkan mereka untuk menerapkan hubungan yang mereka pelajari dengan membaca kata-kata dan cerita-cerita sederhana (Carnine, Silbert, \& Kameenui, 1997; Chard, Simmons, \& Kameenui, 1998). $\begin{array}{ccc}\text { Instruksi } & \text { Phonics } & \text { biasanya } \\ \text { dikategorikan } & \text { sebagai } & \text { eksplisit }\end{array}$ atau implisit. Dalam instruksi fonik eksplisit, bunyi yang terkait dengan huruf diidentifikasi secara terpisah dan kemudian digabungkan bersama untuk membentuk kata-kata. Guru secara langsung memberi tahu siswa bunyi yang diwakili oleh huruf. Misalnya, "Huruf 1 membuat bunyi / 1111 /." Ketika anak-anak telah belajar beberapa korespondensi, termasuk satu atau dua vokal, mereka dapat membaca kata-kata dengan memadukan bunyi dari huruf-huruf itu bersama-sama. Sebagai contoh, siswa yang telah mempelajari korespondensi huruf dan bunyi / I / / a / / m / dan / p / dapat menggunakan strategi blending untuk membaca "lamp."

Sebaliknya, instruksi fonik implisit termasuk membantu siswa mengidentifikasi bunyi-bunyi yang terkait dengan huruf-huruf individual dalam konteks seluruh kata, dan bukan dalam isolasi. Biasanya, siswa diminta untuk menyimpulkan huruf dan bunyi dari sebuah kata atau serangkaian kata yang mengandung huruf itu.

Dalam fonik implisit, anak-anak sering didorong untuk menggunakan konteks dan isyarat gambar untuk mengidentifikasi kata-kata asing yang mereka temui dalam pilihan teks. Kebanyakan program tambahan menggunakan instruksi yang eksplisit.

\subsubsection{Pelayanan terhadap Keragaman Siswa ketika Mengajar Fonik}

Sekolah melayani populasi siswa yang beragam yang mencakup siswa dari 
berbagai latar belakang budaya, sosial, bahasa, agama, ekonomi dan politik dan beberapa yang mungkin memiliki pengalaman pendidikan terbatas atau terganggu. Siswa-siswa ini memiliki beragam kebutuhan, minat, pengalaman, kemampuan, gaya belajar dan kecerdasan. Keragaman ini memberikan manfaat besar bagi siswa itu sendiri dan untuk masyarakat yang lebih luas. Pada saat yang sama, kebutuhan belajar melek huruf yang beragam dari siswa harus diperhitungkan ketika merencanakan, mengajar dan menilai fonik jika semua siswa memiliki kesempatan untuk berhasil belajar.

\section{PENUTUP}

Dalam istilah sederhana, fonik termasuk juga mengetahui hubungan antara huruf cetak (dan kombinasi huruf) dan bunyi ujaran. Sebagai contoh, siswa menunjukkan pengetahuan fonik mereka ketika mereka diminta untuk menunjuk ke huruf $\mathrm{m}$ dan memberikan suara yang dihasilkannya. Instruksi fonik termasuk juga mengajar siswa untuk mengetahui hubungan antara huruf dan suara dan bagaimana menggunakan pengetahuan ini untuk mengenali katakata saat membaca, dan mengeja kata saat menulis. Para ahli berdebat tentang seberapa banyak penekanan harus ditempatkan pada instruksi fonik, tetapi hampir semua setuju bahwa fonik adalah salah satu aspek keaksaraan penting untuk pembelajaran keaksaraan yang sukses. Beberapa anak merasa lebih mudah belajar fonik daripada yang lain karena berbagai alasan, dan seluruh ejaan bahasa Inggris tidak dapat dijelaskan dalam hal fitur yang paling tidak teratur. Fonik adalah contoh dari apa yang disebut matematikawan "logika fuzzy", di mana item tidak selalu berbagi semua karakteristik dari set mereka (dalam hal ini, kata-kata bahasa Inggris).

\section{DAFTAR PUSTAKA}

Abidin, Yusuf Zainal. 2015. Manajemen Komunikasi: Filosofi, Konsep, dan Aplikasi. Bandung: Pustaka Setia.

Adams, M.J.1990. Beginning to read: Thanking and Learning About Print. Cambridge: MA, MIT Press. Justice, L. M., \& Kaderavek, J. 2002. Using Shared Storybook Reading to Promote Emergent Literacy. Teaching Exepcional Children, 8-13.

Kern, Richard. 2000. Literacy and Language Teaching. Oxford: Oxford University Press.

Morissan. 2013. Teori komunikasi: Individu Hingga Massa. Jakarta: Kencana.

Nutbrown, Cathy, dan Clough Peter. 2015. Pendidikan Anak Usia Dini: Sejarah, Filosofi, dan Pengalaman. Yogyakarta: Pustaka Pelajar.

O’Connor, R.E., Notari-Syverson, A., \& Vadasy, P.F. 1998. Ladders to Literacy: A Kindergarten Activity Book. Baltimore: paul bookes.

Perfetti,C.A., \&Zhang, S. 1995. Very Early Phonological Activation in Chinese Reading. Journal of Experimental Psychology: Learning, Memory, and Cognition, 21, 24-33. http://dx.doi.org/10.1037/02787393.21.1.24 
Resmini, N., dan Dadan J. (2010). Stanovich, K.E \& West, R. F. 1997. Pendidikan Bahasa dan Reasoning Independently of Prior Sastra Indonesia di Kelas Belief and Individual Differences in Tinggi. Bandung: UPI Press.

Actively Open-Minded Thinking. Snow, K., Burns, M. S., \& Griffin, P. Journal of Educational Psychology. (Eds). 1998. Preventing Reading 89. $342-357$

Difficulties in Young Children. Subyantoro, 2011. Pengebangan Washington DC: National Academy Press.

Keterampilan Membaca Cepat. Yogyakarta: Graha Ilmu. Suyadi. 2010. PsikologiBelajar AnakUsia Dini. Yogyakarta: PEDAGOGIA. 